\title{
Under the Shadow of Sharia: Christian Muslim Relations from Acehnese Christian Experience
}

\author{
Muhammad Ansor ${ }^{1 凶}$, Yaser Amri ${ }^{1}$, Ismail Fahmi Arrauf ${ }^{1}$ \\ ${ }^{1}$ IAIN Zawiyah Cot Kala, Langsa, Aceh, Indonesia
}

DOI: http://dx.doi.org/10.15294/komunitas.v8i1.4966

Received : 29 January 2016; Accepted: 22 March 2016; Published: 31 March 2016

\begin{abstract}
The implementation of sharia in Aceh is believed to have given certain impacts to the different aspects of life of the Christian, economically, culturally, politically and to the general development as well. Unlike other Indonesian Christian in different parts of the archipelago, the Christian women in Aceh are experiencing the life that regulated by the sharia. They supposed to wear headscraf (hijab) in order to adapt and negotiate with sharia public sphere. They too, are experiencing difficulties to establish their own church beyond the complexities than other Christian adherent in different parts of Indonesia. Intense intra-muslim struggles couples with increased state-mobilized Islamizing efforts have produced disturbing knock-on effects on non-Muslim minorities. This article aims to elucidate key practical issues affecting Christian living in majority Islamic context. This paper is based on the ethnographical studies conducted in the year 2013-2014 in Langsa and Aceh Singkil. It further proposes significant policy options for managing Muslim-Christian relations in Aceh, Indonesia. Education is crucial for promoting interreligious harmony, religious freedom, and respect for people of different traditions and religion.
\end{abstract}

Keywords: Acehnese Christian; inter-religious relations; Islamic law

\section{INTRODUCTION}

As far as had been successfully traced, a study of the relation between Christian as minority and Muslim as the majority who implement Islamic law, has received much attention of experts. Some studies on Christian-Muslim relation had been done by Frieder Ludwig (2008) and Rabiatu Ammah (2007) when discuss the experience of the Christian minority in Nigeria post-implementation of Islamic law. Julis Droeber (2012) discussed the experiences of Jordanian Christian women by focusing on similarities and differences in women's responses to the implementation of Islamic law. Annika Rabo (2012) wrote on gender segregation and religious influences on the formation of the Christian experience as a minority in Syria. George Sabra (2006), Elizabeth Iskander (2012), Laura C. Robson (2010) and A Christian Van Gorder
(2010) wrote on experience of Christian minorities in the Middle East.

Meanwhile, with a similar theme in Indonesia, some researchers had written such studies from the perspective of the Muslim majority (Gramsci 1996; Arifianto 2009; Basedau, Vüllers and Körner 2013; Connolly 2009; Rodemeier 2010). Some of them are Sumanto Al Qurtuby who discussed on Christian Muslim Alliances in peacebuilding among two communities in Ambon Indonesia; Baqir (2013) who discussed inclusive and exclusive views of Muslims about Muslim and Christian relations; and Wahid (2012), examined the view of $\mathrm{Mu}^{-}$ hammadiyah towards Indonesian Christian. Unfortunately, a study that proceeds from a Christian perspective as a minority-especially in Aceh, which implements the Islamic Sharia is almost never found. 
The following article contributes to the debate about the Muslim - Christian relationship in Aceh by focusing on the impact of the implementation of Islamic law on the formation of Christian religious experience. First of all we will discuss the impact of Islamic law on Christian Muslim relations in the format of contemporary Aceh. Furthermore, we will analyze the experience of the Christian minority in Aceh negotiates with the reality of making Islamic law in Aceh as a collective identity for its society. The article focused on discussing the experience of Christians Acehnese in Aceh Singkil and Langsa. These two areas have been selected as the locus of research because of the dynamics of Muslim and Christian relations lately quite high, so it could be expected to represent a portrait of the relationship between Muslims and Christians in contemporary Aceh (Qurtuby 2013).

\section{RESEARCH METHODS}

This study utilized grounded theory, a type of qualitative research that lead to a theory grounded in the data (Creswell 2007; Glaser 2007). Field data used in this paper were collected during the last two years. Field data was collected in Aceh Singkil during January to February, 2013, while the data in Langsa in March to November, 2014. Data was collected through semi-structured interviews, observation and focus group discussion (FGD). In Aceh Singkil researchers interviewed the Christian leaders Norim Brutu (an eminent figure of Siatas GKPPD church), and Astia Gajah (a leader in Kuta Karangan GKPPD church). In Langsa, the researchers interviewed Purba and Hutasoi (figures of HKBP Langsa) and Tet San (figure of Bethel Church of Indonesia [GBI] Langs). In addition, researchers also interviewed seven Christian women who come from different backgrounds, such as teacher, nutrition expert, village's secretary, student, and housewives. The observations focused on the daily life of Christians in three areas during the period of research is conducted, be it the activities in the workplace, places of worship and other public spaces. While FGD was only done twice in Langsa with about 10 participants in each session of focus group discussion.

Researchers recorded each interview and afterward wrote the transcription of the interview verbatim. Researchers also made field notes on observations made on the day when the observation is made. In relation to FGD, the researcher recorded the discussion in audio visual and wrote textually the transcription of discussion process. Moreover, the researchers also asked a number of questions to the participants who were requested to give their response in writing. Most of the interview transcripts were confirmed to the related informants in order to clarify the view that they have said during the process of interview as well as FGD process. Furthermore, researchers analyzed the data and presented a discussion as seen in the structure of the following article. The first part is the introduction. The second part described the portraits of Christians in the discourse of Islamic law in Aceh. The third section contained answers to research problems by elaborating the Christian experience in the three areas. Paper ends with conclusions and recommendations.

\section{RESULTS AND DISCUSSION}

\section{Aceh as the Stage for Islamic Sharia}

The stage play about Aceh has only one ornament: Islam. Islam has been a core feature of Aceh politics and society since at least the twelfth century when archeological evidance at Kuta Lubhok in Aceh Besar suggested the existence of an Islamic community south of capital Banda Aceh (McKinnon 2006, p.30). By the sixteenth and seventeenth centuries, Aceh had attained a period of imperial greatness marked by its political and spritual dominace in the region. By 1950 it was known as "the intellectual and spritual centre of Islam in the Malay world", which reached its height in the seventeenth century (Stenbrink 2006, p.40). The strategic importance of Aceh as the Islamic center of Southeast Asia, indeed as Serambi Mekkah, during this time, reflected its flourising reputation for Islamic scholarly excellence and the dyinamism of doctrinal debates. The latter had 
tremendous impact on religious groups in Aceh and the rest of the region (Smith 2007, p.43-49).

Ducth occupation of Aceh in 1873 shaped what would becames Aceh's core identity feature, i.e. an Islamic identity based on a passionate and vigorous reaction agains non-believer, oppression and colonization. The "holy war of faith" (militant jihad or Prang Sabil) is resonant in its history. It was first pursued by Acehnese Sultans in the sixteenth and seventeenth centuries against the Portuguese in Melaka, including nonBataks, the Ducth from 1873 to 1930s, the Japanese from 1941 to 1945, and against Javanese oppression starting 1945 to the present (Milallos 2007, p.292).

Within an independent Indonesia, Aceh officially became an autonomous province in 1950. This was abolished in 1951 following mounting political tensions. ThenAceh Governor Daud Beureu'eh quickly seized the opprtunity to lounch a Darul Islam military campaign against the central Governement (Parekh 2008, p.153-156). The justification for the revolt as jihad (holy war) was two-fold: to establish an overaching Pancasila ideology, and to demonize those who oppose the first objective as enemies and thus are kafir and apostases (Parekh, 2008 p.154). As a response, starting with Soekarno's government and most notably during Soeharto's New Order the military followed sustained counter-insurgency campaigns. This has resulted in Aceh's systematic political and economic retardion, and the strenghening of its peculiar brand of identity. In 1976, the Gerakan Aceh Merdeka (GAM, or the free Aceh Movement) was born. Demonds for the establishment of Islamic state became synonymous with calls for political independence (Milallos 2007, p.292).

As the great economic crisis that hit Asia in 1997-1998, the reform movement was launched following the collapse of the New Order government. One of the effects of the reform is the emergence of Islamist groups who are demanding the implementation of Islamic law through the political-state approach. Some particular groups that experi- enced repression from the New Order regime for more than three decades then played an important role in the transition process. In the case of Aceh, the opening of Pandora's Box gave impact on strengthening Aceh Liberation Movement which is militaristic in feature. In the reign of Megawati, Aceh region was even defined as a region of military operation. Political change has significant implications for the dynamics of social life on the people of Aceh. Jakarta responded the case of Aceh by issuing Law No. 44/1999 regarding Aceh privilege and its authority in the implementation of Islamic law.

Aceh in the post-reform era experienced fundamental change in terms of formal Islamic position as a source of social order setting. The majority of Acehnese Muslims believed that the implementation of Islamic law in Aceh in 2001 is the return of the rights of Acehnese that has been lost since the colonial period. Arskal Salim (2008, p.156-162) noted that the establishment of Aceh's special status for the implementation of Islamic law was soon followed by publishing a number of Qanun on Islamic Law, either which regulated the formation of the new institution about Islamic law or regulated aspects of socio-religious life. Let say for example the publication of Regulation No. 3/2000 on the establishment of the Consultative Assembly of Ulema, and Qanun No. 10/2003 on the Sharia Court, Qanun 9/2003 on the functional relationship between the MPU with the legislative, executive and other government agencies in Aceh. In relation with the regulation of Islamic law in the community, the government of Aceh published Qanun 11/2002 on the implementation of Islamic law in the field of faith, worship and propagation of Islam; Qanun 12/2003 on the prohibition of liquor (Khamr); Qanun 13/2003 on the prohibition of gambling; Qanun No. 14/2003 on the prohibition of seclusion; and Qanun No. $7 / 2004$ on the regulation of zakat.

\section{Christian and Sharia in Aceh}

The position of non-Muslims in the regulation of Islamic law in Aceh can be traced from the Qanun No. 05/2000 on the imple- 
mentation of Islamic law. Qanun asserted that "the existence of other religions outside of Islam continues to be recognized in this region; its followers may live according to the teachings of their religion". This dictum normatively recognizes the existence of non-Muslims in Aceh. They are respected, protected, and given the freedom to worship according to the teachings of their religion (Marzuki 2010, p.164-165). Although dictum is quite firm, but since the beginning the non-Muslims have concerns about their position in the discourse of Islamic law in Aceh. Such concerns primarily related to equity of access and equity as a part of the citizens of non-mainstream religion.

These concerns are quite reasonable since several Islamic laws in Aceh Qanun directly related to the limitation of access to their religious rights. At least this is seen in the Qanun No. 11/2006 on Aceh government. It states that the contruction of a place of worship in Aceh requeres the permission of the Provincial Aceh Government and the city/regency governement. This provision is an attempt by the Acehnese governement to assert its authority over the permit aplication process. It was anticipated that a Qanun on places of worship would provide more details at the later stage. The first step towards this occured in Juli 2007, when the Governor of Aceh passed Regulation 25/2007 on Places of Worship. This requered applicants for a place of worship to obtain the signatures of at least 150 members and the approval of at least 120 local residents (Kymlicka 1995).

Aceh government policies restrict religious buildings for worship affect to the dynamics of non-Muslim religious life. They are difficult to build a worship place though the congregation has increased either due to marriage or birth. Usually, their worship place is invaded by the masses because they don't have a permit. For example, in Peunayong Banda in the mid-2012 an Indonesian Bethel Church (GBI) which was considered not to have a permit was mass assaulted. Likewise, the GBI community in Langsa faced similar situation. Tetsan, Langsa GBI officials told us that the place which was accused by the people as a church is not truly a church, but it is an ordinary place where they do worship, because they do not have their own church. GBI Langsa not actually intended to build a church, but they just need a place where they can conduct religious activities and worships.

Tabel 1. Number of worship places and its worshipers in Aceh

\begin{tabular}{|c|c|c|c|}
\hline & $\begin{array}{l}\text { Name of Worship } \\
\text { places }\end{array}$ & $\begin{array}{l}\text { Num- } \\
\text { ber of } \\
\text { Worship } \\
\text { places }\end{array}$ & $\begin{array}{l}\text { Users } \\
\text { (per- } \\
\text { sons) }\end{array}$ \\
\hline 1. & Mosque (Muslim) & 3.991 & \\
\hline & $\begin{array}{l}\text { Meunasah } \\
\text { (Muslim) }\end{array}$ & 7.816 & 4.413 .244 \\
\hline 3. & $\begin{array}{l}\text { Church } \\
\text { (Protestant and } \\
\text { Catolic) }\end{array}$ & 154 & 53.624 \\
\hline & Vihara (Budha) & 14 & 7.062 \\
\hline & $\begin{array}{l}\text { Klenteng } \\
\text { (Konghuchu) }\end{array}$ & 2 & 318 \\
\hline
\end{tabular}

Source: BPS Aceh province, year 2010

An other problem faced by Acehnese Christian is related to Qanun No 11/2002 which regulate the obligation of wearing Muslim dress while show up in public spaces like school, government institution, private institution or alike, non-Muslim women are often requested to adapt their selves with the condition. The dress, nowadays, becomes one of the significant issues in formatting Muslim-Christian relation in Aceh. Mass media broadcast about the appeal of Wilayatul Hisbah (WH) for the nonMuslim to wear veil became the hot topic in mass media, printed and electronic (Jakarta Globe, February 7, 2013). Non-Muslim women in Langsa, for instance, afraid of going out of their home unveiled or don't meet the standard of Muslim dress due to frequent raid on dress conducted by the authorities. According to their confession, as a non-Muslim they are not necessarily trusted by the sharia police, they would be stopped in a raid by the police since they don't wear veil. This caused about 49 families out of 108 that affiliated to langsa HKBP church have to wear veil in perforce or at least have ever 
wore veil on certain occasion. Not only that, out of 21 women whose profession are teachers, 16 of them wear veil at their workplace (Ansor 2013)

The feeling of being discriminated is also experienced by the students in school public space. Yuli, a teacher of an SMK (vocational school) in Aceh Tamiang often feels the suspicion of part of Muslim teachers related with the learning strategy that she applies in the school. English language learning system applied by her is suspected of containing matters which may weaken the faith of the students since she is a Christian (An interview with Yuli 2013). In Langsa, Mayesty, a university student, feels that certain lecturers at her campus often discredit her religion while delivering their lectures (An interview with Mayesty 2013). Grace, a school student, told us that she wanted to finish her school as early as possible so that she may continue her study to a higher learning institution outside Aceh and free from the current situation that consider her as the second class citizen because of her religion (An interview with Grace 2013).

Other issue that made up the format of Muslim-Christian relations in contemporary Aceh is related to the issue of Christianization and apostasy. The growth of Christian population over the last 14 years believed as a sign of the widespread of Christian population, which was predicted not only by birth but conversions. Problem arose when in 2011 the Aceh vice governor, Muhammad Nazar in a religious speech said about 20,00o Acehnese converted to non-Muslim. But the numbers cited by Nazar is considered unfounded and exaggerated because the growth of Christians population in Aceh based on BPS 2010 data, compared with the data in 1994, it do not reach that number. In 1994, research body of the Ministry of Religious Affair stated that the non-Muslim population in Aceh are 51,586 people (Mubarok 1994, p.99), while according to the 2010 BPS Census, the Christian population in Aceh are 53,624 people, in which the increase number over the 14 years are 2,038 people. It seems to us that the growth rate is relatively normal if not to say tend to slow.
However, regardless of the truth of the data presented by Nazar, conversion issue has become crucial conversations that make up tensions between the Muslim-Christian relations in contemporary Aceh.

\section{Inter-Faith Relation and Christian Ex- perience}

We elaborated the Christian experience of Aceh on Muslim-Christian relations in Langsa and Aceh Singkil by highlighting two different cases. In Langsa, we elaborated the experience of Christian women related to regulation of veil; women have to wear veil in public spaces. In Aceh Singkil we explored the Christian experience related to the sealing of worship places that occurred in 2012. Those cases are analyzed based on the research questions posed in the introduction that is how the implementation of Islamic law has an impact on the formation of religious experience of Christian minority in both areas.

\section{The Cross Behind the Veil: Experience of Langsa Women}

The population of Christians in Langsa is considered minority. Out of 200 thousand Langsa populations, the Christian population is not exceeded than a thousand people. Based on the BPS census of 2010, Christian's number is about 655 people, while HKBP officials noted that Langsa Christians numbered 127 families. Outside HKBP, Langsa Christian church incorporated as GBI (Gereja Bethel Indonesia) Langsa branch, which numbered less than 50 people. Christians in Langsa scattered at various jobs such as members of the military / police or retired, private employees, and some of them work as servants in government agencies such as teachers, medical workers and other staff.

One of the interesting phenomenons to be discussed related to phenomenon of interfaith relation in Langsa was the widespread of Christian women who wear veil in her daily appearance. Based on the data collected, from about 21 female civil servants, as many as 16 people are wearing the veil when she appeared in a public space, either at work, such as a school, college, office, or 
any other public places. Based on the search of the 108 families who are affiliated with HKBP Langsa, found there were 49 families in which the women in the family has the experience of wearing veil, or at least once when appearing in public spaces. Almost all student (female) of Samudra University (numbering approximately 8 people) wear veil at campus; while some students in high school (Senior High School) senior and junior (Junior High School) wear veil at their school.

The phenomenon of Christian women wearing veil in Langsa is interesting to be scrutinized because the qanun of Islamic law does not apply to Christians. Qanun No. 11/2002 of Islamic law, chapter 13, and verse 1 clearly states that "every Muslim is obliged to wear Islamic dress". Same chapter in verse 2 asserts "any government agencies, educational institutions, business entities, and civil society institutions are obliged to accustom Islamic dress". These two articles are confirming the position of non-Muslims to be exempt from these regulations. The compulsory of Islamic dress is only addressed to Muslims, and is not intended to non-Muslims. However, the regulation saying that public institutions have to cultivate and accustom Islamic dress cause double interpretation. The article does not explicitly mention the exclusion of non-Muslims who work in the institution of public or governmental institutions. As a result, leaders of public institutions sometimes also demanded the participation of non-Muslims to 'habituate Islamic dress', by wearing veil while at work.

Based on interviews conducted, nonMuslims admitted that they verbally are often encouraged to conform to these provisions. Christian university student in Langsa said that the university where they study requires female students to meet the standard of Islamic dress. Christian women are not explicitly instructed to wear veil, but they felt they had no other choice but to adjust. Mayesti and Elida, students of Samudra University said they wear veil at campus. According to Mayesti, she wears veil because she does not want to look weird because she was the only woman who is not veiled. Elida said that there is no written notice in campus which states that non-Muslim should wear veil, but since she first entered campus, she was told to wear it when she is in campus.

The Christian student in high school partly veiled. Based on the observation it appeared that all Christian girls of Chinese ethnic do not wear the veil. But Batak women, split into two, partly veiled, while others are not veiled. The schools generally do not publish a written policy that nonMuslims should wear the veil, although in particular schools there are some banners contains the message"compulsory Islamic dress region". The veiled Christian girls we interviewed had various experience of the backgrounds of wearing veil. Among those who say there are already familiar with the veil, as has been wearing veil since junior high school. But there are some girls who choose to wear the veil because often their friends or teachers encouraged them to wear veil. A school teacher said the school does not require non-Muslim girls to wear veil, although we found the school mounted billboards containing Islamic dress appeal without exception of religious background.

The majority of female teachers in Langsa wear veil at school. Only four teachers out of 21 teachers in Langsa do not wear veil at school. They have a variety of experiences regarding the reason behind wearing the veil. However, based on the intensity of wearing veil, Christians female can be grouped at least into two, first one are those who wear it only at school, and the second one are those who wear it in every activity in a public spaces. Veiling at school among Christian women is the attitude of the majority of female teachers in Langsa. It should be noted that generally Christian female teachers had the support of the family when they decide to wear veil. In addition, the majority of women teachers are wives of military / police, so they are also listed as members of Persit or Bhayangkari that in formal occasion and official meetings wear veil.

It is interesting to be observed that although there is no written instruction to non-Muslim women in wearing veil, but 
in fact they are veiled when appearing in public spaces. Environmental conditions in which women generally wear veil in Langsa greatly influence their decisions to adapt and likewise, wear it. In addition to that, the frequent raids on Islamic dress conducted by DSI (Department of Islamic Law) also affect their decision. Using Pierre Bourdieu's perspective of habitus, the fact that Muslim and Christian women in Langsa share the same space in their daily activity also affects their decision to wear veil. Above all, the minorities usually choose to adapt to trends and values adopted by majority groups as part of the efforts to be accepted by the majority. However, in the case of Christian women wearing veil, such phenomenon thus something interesting to discuss because they act according to other's religion, not based on their own religion.

\section{Church without the Cross in Aceh Sing- kil}

The pattern of Muslim-Christian relation in Aceh is also formed by the discourse of church construction. Aceh has a fairly strict protection system to prevent the growth of Christian population. The efforts made through at least three things. First, issuing sanction for perpetrators of apostasy or conversion to other religion. Second, tighten the requirement of church construction. Third, restrictions on non-Muslims access to employment opportunities in government institutions. We will not discuss these three issues in this paper, but it is limited to the issue of the construction of the church, especially based on the experience of Christians in Aceh Singkil.

The requirements for the construction of church in Aceh are more stringent than the regulations applicable in Indonesia. SKB (Joint Decree) of three ministers on the construction of worship place mentioned the requirement of at least 90 users, and supported by 60 people of other religions evidenced by a signature and a copy of the identity of the population. But the Aceh government requires 150 users, and supported by 120 community members who had been validated by the local headman. Implemen- tation tightened with the unwritten conventions that prohibit the construction of new churches in the region of Aceh. Muslim sociological conditions which generally reject the construction of the church further complicate the position of Christians. As a matter of fact, in recent decades, almost no church has been built in Aceh. This is quite apprehensive because Christian population will continue to grow naturally as a result of wedding or birth.

Aceh Singkil is an area with a Christian population is second in rank after Southeast Aceh. Southeast Aceh Christian populations are 33,484 people (18 per cent) out of total population of 179 ,010 inhabitants. While the Christian populations in Aceh Singkil are 11,461 (10 percent) out of the total population of 101509 inhabitants. Total Christians Acehnese populations are 53,624 people (about 1 percent of the population in Aceh between five million inhabitants), hence the existence of Christians in these two districts have a significant social and political role. It needs to inform the number of churches in Aceh, there are as many as 127 churches. No data is available on the number of government-recognized church, but is not expected to be a quarter of the total church in Aceh. In Aceh Singkil alone, out of 27 churches, government recognizes only one church and four undung-undung (similar to musholla in Islamic religion). Most of the church is not recognized even though it is built in the village with almost hundred percent of the population are Christians.

The concept of undung-undung is the typical of Aceh Singkil, although the term is actually known in the holy book and the history of the church in Israel. The concept of undung-undung according to Astia Gajah (Kuta Karangan GKPPD board) is used as a form of negotiation between Christians with the local government regarding the number of recognized churches in Aceh. Historically, the conflict between Christians and Muslims in Aceh Singkil is longstanding. In the 1970s, in the event of a conflict and the burning of several churches in the territory of Aceh Singkil, the local government recognized GKPPD Kuta Karangan District 
of Simpang Kanan as official church. But due to large Christian populations and the condition of their settlement are far apart, Christians invoke the government to recognize four churches in Napagaluh village of the Lake Paris Sub-district; in Keras village of Suro Sub-district; in Suka Makmur village of Gunung Meriah sub-district; and Lae-Gecih village of Simpang Kanan sub-district. Application is granted with the requirement that smaller church could be built namely undung-undung. It is also prohibited to put a cross on undung-undung as it usually hung on the front side of the church. This regulation is obeyed by Christians, so up to now the four undung undungs are known as the church without a cross.

In addition to a church and four undung undungs that have been recognized by the government, there already have been many churches in Aceh Singkil. Astia Gajah noted that at that time (the 1970s) actually a dozens of churches have been existed. The local government requested the destruction of those unrecognized churches, but Christians did not destroy them. The number of churches in Aceh Singkil continued to grow in line with population growth of Christians. Apart from that, the development of other denominations within Christianity also led to the construction of new churches in recent years. In 2012, the total churches in Aceh Singkil as recorded by Astia Gajah are as many as 27 and more than half of them are affiliated to Kuta Karangan GKPPD.

In 2012, Aceh Singkil became the concern of not only by national media, but also international, because local government banned about 20 unrecognized churches. The ban was rooted from the demonstration launched by Forum Umat Islam (FUI) and Front Pembela Islam (FPI) of Aceh Singkil that urge the government to clean up unrecognized churches. Regarding the permit, the board of Siatas GKPPD said that they have long proposed to establish place of worship. But the application was not responded by local government. Moreover, the tension between Muslims and Christians also caused the refusal of the local Muslim population to sign no objection declaration form and denied to give a copy of the identity card. The rejection was due to propaganda launched by the border preachers to draw their support over the construction of the church.

The ban of the churches in Aceh Singkil cannot be separated from the political events that took place in the district. In 2012, Aceh Singkil conducted elections. The previous Regent of Aceh Singkil, Makmur Syahputra (died a year before his period is finished) has a hard effort in developing harmony of religious life in Aceh Singkil. In 2007 election, Makmur Syahputra received strong support from the Christians as it is considered capable of protecting minorities. By mid 2012, the governor of Aceh inaugurated Razali AR as the Acting Regent. A few months later the government banned churches on the grounds of having no permit. But many people speculated that the ban of the church cannot be separated from local political events that took place. In 2012 election, Christians are considered decisive over the victory of Syafriadi Manik. In areas with Christian as majority, Syafriadi got full support. Ban of the church was accused by some groups as the result of the sentiment over the victory of Syafriadi with the support of the Christian minority. After the inauguration of Syafriadi as regent, the issue of church ban subsided, although Christians still do not get the permit to build church.

\section{CONCLUSION}

Although Islamic law is only directed to Muslims, but in fact non-Muslims are also experiencing the impact of the policy. Compared to the male, non-Muslim women get more of a direct impact of the policy. Most impact is felt primarily related to the implementation of Islamic dress codes. The article shows that althought Christian women understand that they are not bound by the Qanun of Islamic law; routine raid on fashion, the appeal to non-Muslims to meet the Islamic dress code or to respect the Islamic law, the environment of work place (activities) that implements the mandatory of Islamic dress, or other daily experiences; limited their choice, they have no other choi- 
ce unless to wear veil in public spaces.

Another issue that affect the format of the Muslim-Christian relations in Aceh is related to the construction of the church despite the regulation of the construction of worship place issued through three ministerial joint decree causing controversy, Aceh step further by tightening the requirements. The three ministerial joint decrees mention the construction of the worship place require to having 90 worshippers and supported by 60 local community members from other religious adherents; while Aceh governor regulation requires 150 worshippers and the support of 120 community members. For Christians in Aceh, to seek the support of community members is not an easy job, because the socio-religious Muslim community in Aceh sometimes accept the nonMuslim neighbors, but at the same time they refuse to provide support related to the construction of houses of worship.

Marginalization of Christians in sharia public space becomes the daily experience of minorities in Aceh (see also Gorder, 2010; O'Mahony, 2010). One of the reasons is the lack of understanding about religious tolerance among Muslims. Therefore at the end of this article we recommend the importance of promoting religious tolerance among Muslims. Discrimination suffered by non-Muslims in Langsa and Aceh Singkil or Aceh in general triggered by low awareness of religious tolerance, especially the intolerance of majority against the minority (see also Haron, 2007:257-273; Yusuf, 2010). Therefore, it needs to strengthen tolerance insight and awareness of diversity in the Muslim community in Aceh, either through education in universities, schools, boarding schools (pesantren), public lecture (pengajian) or society in general.

\section{ACKNOWLEDGEMENT}

Early draft of this paper presented at The 3rd International Conference on Multidisciplinary Research (ICMR) held in Medan October 16-18, 2014. The author would like thank the convenor for all their valuable feedback and critical comments on the original article; to anonymous reviewer for contributing ideas that enriched this paper, and to the journal editor for chance to publish our paper.

\section{REFERENCES}

Al Qurtuby, S., 2013. Peacebuilding in Indonesia: Christian-Muslim Alliances in Ambon Island. Islam and Christian-Muslim Relations. 24(3), pp.349-367.

Ali-Fauzi, I., et al., 2011. Kontroversi Gereja di Jakarta. CRCS Universitas Gadjah Mada, Yogyakarta.

Ammah, R., 2007. Christian-Musim Relations in Contemporary Sub-Saharan Africa. Islam and Muslim Christian Relations. 18(2), pp.139-153.

Ansor, M., 2013. Yang Bersalib Yang Berjilbab: Politik Representasi dan Negosiasi Identitas Perempuan Kristen Langsa. Puslitbang Kehidupan Keagamaan Kementerian Agama, Jakarta. Unpublished.

Arifianto, A.R., 2009. Explaining the cause of MuslimChristian conflicts in Indonesia: Tracing the origins of Kristenisasi and Islamisasi. Islam and Christian-Muslim Relations, 20(1). pp.7389 .

Baqir, Z.A, et al., 2013. Laporan Kehidupan Beragama di Indonesia 2012. CRCS Universitas Gadjah Mada, Yogyakarta.

Basedau, M., Vüllers, J. and Körner, P., 2013. What drives inter-religious violence? Lessons from Nigeria, Côte d'Ivoire, and Tanzania. Studies in Conflict \& Terrorism. 36(10), pp.857-879.

Connolly, J., 2009. Forbidden Intimacies: ChristianMuslim Intermarriage in East Kalimantan, Indonesia. American ethnologist. 36(3), pp.492506.

Creswell, J.W., 2007. Qualitative Inquiry and Research Design: Choosing among Five Approaches. $2^{\text {nd }}$ ed. SAGE Publication, Thousand Oaks, CA.

Droeber, J., 2012. We Are Different! Similarities between Christian and Muslim Women in Jordan" Islam and Muslim Christian Relations. 23(1). pp.59-78.

Glaser, B.G., 2007. Doing Formal Theory. The SAGE Handbook of Grounded Theory. A Bryant \& K. Charmaz (ed). SAGE Publications, Thousand Oaks, CA.

Gorder, A.C., 2010. Christianity in Persia and the Status of Non-Muslim in Iran. Lexington Books, New Yorks.

Gramsci, A., 1996. Selection From The Prison Notebooks. Orien Longman, India.

Haron, M., 2007. Christian-Muslim Relations in South Africa (circa 1986-2004): Charting Out a Pluralis Path. Islam and Christian Muslim Relations, 18(2). pp.257-273.

Howard, D., 2013. Islam and Christianity: On 'Religious of Law. Islam and Christian Muslim Relations. 24(2), pp.173-189

Iskander, E., 2012. The 'Mediation' of Muslim-Christian Relation in Egypt: The Strategies and Discourses of the Official Egyptian Press Dur- 
ing Mubarak's Presidenc". Islam and Christian Muslim Relations. 23(1), pp.31-44

Kyimlicka, W., 1995. Multicultural Citizenship: A Liberal Theory of Minority Right. Oxford University Press, New York.

Ludwig, F., 2008. Christian-Muslim Relations in Northen Nigeria since the Introduction of Shari'ah 1999. Journal of the American Academy of Religion. 76(3), pp.6o2-637.

Marzuki. 2010. Kerukunan dan Kebebasan Beragaman dalam Pelaksanaan Syariat Islam di Aceh. Jurnal Harmoni. 9(36), pp.157-170

McKinnon, E.E., 2006. Indian and Indonesia Elements in Early North Sumatra, in Anthony Reid (ed.), Verandah of Violance: The Background to the Aceh Problem. Singapore University Press, Singapore.

Milallos, Ma. T.R., 2007. Muslim Veil as Politics: Political Autonomy, Women and Syariah Islam in Aceh. Contemporary Islam. 1, pp.289-301.

Mubarok. 1994/1995. Rangkuman Peta Kehidupan Keagamaan Indonesia. Balitbang dan Pengembangan Agama Kementerian Agama, Jakarta.

Mujiburrahman. 2006. Feeling Threatened: MuslimChristian Relations in Indonesia's New Order. Amsterdam University Press, Leiden.

O'Mahony, A. \& Loosley, M., (ed). 2010. Eastern Christianity in the Modern Middle East. Routlegde, London and New Yorks.

Parekh, B., 2008. Rethinking Multiculturalism: Keberagaman Budaya dan Teori Politik. Penerbit kanisiun dan Impulse, Yogyakarta.

Rabo, A., 2012. We Are Christians and We Are Equal
Citizens': Perspectives on Particularity and Pluralism in Contemporary Syria. Islam and Muslim Christian Relations. 23, pp.79-93.

Robson, L.C., 2010. Palestinian Liberation Theology, Muslim-Christian Relations and the ArabIsraeli Conflict". Islam and Christian Muslim Relations. 21(1), pp.39-50.

Rodemeier, S., 2010. Islam in the Protestant environment of the Alor and Pantar islands. Indonesia and the Malay World, 38(110), pp.27-42.

Sabra, G., 2006. Two Ways of Being a Christian in the Muslim Context of the Middle East". Islam and Christian Muslim Relations. 17(1), pp.43-53.

Safrilsyah. 2012. 'Non-Muslim Under the Regulation of Islamic Law in Aceh Province', Paper presented ini AICIS XII , Surabaya.

Salim, A., 2009. Challenging the Secular State: The Islamization of Law in Modern Indonesia. University of Hawai Press, Honohulu.

Smith, J.I., 2007. Muslims, Christians, and the Challenge of Interfaith Dialogue. Oxford University Press, New York.

Stenbrink, K., 2006. Dutch Colonialism and Indonesian Islam: Contact and Conflict 1596-1950, Rodopi, Amsterdam.

Wahid, Y.Z., 2012. Laporan Akhir Tahun Kebebasan Beragama dan Intoleransi 2012. The Wahid Institute dan Yayasan Tifa, Jakarta.

Yusuf, H.B., 2007. Managing Muslim-Christian Conflicts in Northen Nigeria: A Case Study of Kaduna State. Islam and Christian Muslim Relations. 18(2):237-256 